\title{
Digestibility, ingestive behaviour and performance of non-descript breed hair lambs of different sexual classes subjected to feed restriction
}

\author{
R.T. de Souza Rodrigues ${ }^{1,2,3}$, M.L. Chizzotti' ${ }^{2}$, S. Rodrigues Martins ${ }^{1}$, M.A. Ávila Queiroz ${ }^{1}$ \\ and K. Costa Busato ${ }^{2}$ \\ ${ }^{1}$ Federal University of São Francisco Valley, Department of Animal Science - UNIVASF \\ Petrolina, Pernambuco 56300-990, Brazil \\ ${ }^{2}$ Federal University of Lavras - UFLA, Department of Zootecnia \\ Lavras, Minas Gerais 37200-000, Brazil
}

KEY WORDS: intake, rumination, scarce supply, semiarid, sheep

Received: 6 January 2014

Revised: 26 February 2014

Accepted: 12 June 2014

${ }^{3}$ Corresponding author:

e-mail: rafael.nutricao@hotmail.com

\begin{abstract}
The aim of this work was to evaluate the effect of feed restriction and sexual classes on digestibility, ingestive behaviour and performance of nondescript breed hair lambs. Forty-five animals (15 males, 15 castrated males and 15 females) were distributed in a completely randomized $3 \times 3$ factorial design, with three feeding levels: ad libitum feeding (positive energy balance), $70 \%$ restriction of the ad libitum intake (maintenance level) and $80 \%$ restriction of the ad libitum intake (negative energy balance). For all variables, there was no effect of sexual class nor interaction of sexual class with feeding levels $(P>0.05)$. Animals fed restricted diets had a higher rumination time per unit of dry matter intake $(P<0.05)$. Digestibility was higher in feed-restricted lambs $(P<0.05)$. Weight gain and feed efficiency were lower for feed restriction $(P<0.05)$. Sexual class did not affect intake, digestibility, ingestive behaviour, or performance. Feed restriction affected digestibility and ingestive behaviour.
\end{abstract}

\section{Introduction}

The Northeast region has the largest sheep herd in Brazil with $55.5 \%$ of the national total (IBGE, 2012). Sheep breeding is one of the main economic activities of the semiarid northeast, mainly for meat production, which satisfies much of the demand for animal protein for the local population, as well as being one of the most important sources of income for family farming. Nevertheless, livestock is affected by feed shortages due to long droughts that frequently occur in the region. This is because farmers depend on native forage and it is not a usual practice to store animal fodder.

Non-descript breed hair lambs (NDL) represent most of the sheep herd in north-eastern Brazil. They originated from random mating of breeds introduced by Portuguese colonizers and are characterized by their rusticity and adaptation to semiarid conditions, such as scarcity of water and feed. Nevertheless, there are no studies with restricted-fed NDL. Recent studies have shown that the ingestive behaviour and 
digestibility of wool sheep and cattle were affected when feed restriction was used to increase nutrient utilization (Galvani et al., 2010; Dias et al., 2011).

Furthermore, there are no studies on the performance of NDL of different sexual classes. It has been reported in the literature, however, that males have higher average daily gain (ADG) and better feed efficiency (FE) than castrated males and females due to the anabolic effect of testosterone (Schanbacher et al., 1980; Jenkins et al., 1988).

Thereby, our hypothesis was that the digestibility and ingestive behaviour of NDL could be affected by feed restriction. Furthermore, the performance of NDL could be affected by sexual class. Thus, this study aimed to evaluate the effect of different sexual classes and levels of feed supply on intake, digestibility, ingestive behaviour, and performance of NDL.

\section{Material and methods}

The experiment was conducted at the Department of Animal Production and Laboratory of Animal Nutrition of the Agricultural Sciences Campus of Universidade Federal do Vale do São Francisco (UNIVASF, Brazil). The climate of the region, according to the Köppen classification, is of the "hot semi-arid' (Bsh) type, characterized by high temperatures, low humidity, high evaporation rates, and especially marked by the scarcity and irregularity in rainfall distribution. According to the Laboratory of Meteorology and Bioclimatology of UNIVASF, during the experimental period, from May to July of 2010 , the average daily temperature was $25^{\circ} \mathrm{C}$ and the average relative air humidity was $62.7 \%$.

The experimental procedures performed in animals were approved by the bioethics committee of UNIVASF (0010/040713). Forty-five animals were used (15 males, 15 castrated males and 15 females), with an initial body weight of $18.1 \pm 0.4 \mathrm{~kg}$ and average age of five months. The lambs were distributed in a completely randomized $3 \times 3$ factorial design with three sexual classes and three feeding levels, and five replicates.

The animals underwent a 30-day adaptation period to the experimental diet and pens, during which they were weighed, identified and treated against ecto- and endoparasites. The castrated males were already acquired in this state; castration had been performed with the use of a burdizzo when the lambs were approximately three months old.

The different feeding levels aimed to provide different levels of energy balance to animals. Feeding levels were: ad libitum feeding (positive energy balance), restriction of $70 \%$ of ad libitum intake (maintenance level) and restriction of $80 \%$ of ad libitum intake (negative energy balance). Dietary restriction was calculated according to intake observed during the last week of the adaptation period with the amount offered being adjusted for the body weight of the animals.

The diet was formulated according to the recommendations of the NRC (2007) for males, consisting of fresh chopped elephant grass (Pennisetum purpureum) and a concentrate based on maize and soyabean meal, in a roughage-to-concentrate ratio of 40:60 (Tables 1 and 2), offered to the lambs twice a day as a total mixed ration, at 07.00 and $16.00 \mathrm{~h}$. All animals received the same diet, varying only in the amount offered.

After the adaptation period, the lambs were kept in a feedlot for 58 days, divided into two experimental periods of 29 days, in which they were weighed before feeding for the determination of ADG and FE. The animals were housed in individual, concrete-floor pens, fitted with individual feed and water troughs. Lambs in the ad libitum treatment were allowed a feed refusal rate of $20 \%$. The animals had unlimited

Table 1. Dry matter (DM), ash, organic matter (OM), crude protein $(\mathrm{CP})$, ether extract (EE), neutral detergent fibre (NDF) and non-fibre carbohydrates (NFC) of feed used in the diet

\begin{tabular}{llllrlll}
\hline Feed, \% & DM & Ash $^{1}$ & OM $^{1}$ & CP $^{1}$ & EE $^{1}$ & NDF $^{1}$ & NFC $^{1}$ \\
\hline Elephant grass & 24.0 & 9.9 & 90.1 & 4.2 & 3.1 & 72.0 & 10.8 \\
Soyabean meal & 90.1 & 7.2 & 92.8 & 46.0 & 0.8 & 16.0 & 30.0 \\
Ground maize & 90.2 & 2.2 & 97.8 & 8.0 & 4.0 & 15.0 & 70.8 \\
\hline${ }^{1}$ dry matter basis & & & & & & &
\end{tabular}

Table 2. Proportion of ingredients and chemical composition of the diet

\begin{tabular}{lr}
\hline Indices & \\
\hline Ingredients, \% dry matter & \\
elephant grass & 40.0 \\
ground maize & 28.6 \\
soyabean meal & 29.5 \\
sodium chloride & 0.5 \\
commercial premix ${ }^{1}$ & 1.1 \\
urea & 0.3 \\
Nutrients & \\
dry matter, \% & 63.8 \\
organic matter, \% DM & 92.7 \\
ash, \% DM & 7.3 \\
crude protein, \% DM & 17.9 \\
ether extract, \% DM & 2.9 \\
neutral detergent fibre, \% DM & 37.9 \\
non-fibrous carbohydrates, \% DM & 33.9 \\
digestible energy ${ }^{2}, \mathrm{Mcal}^{-1} \mathrm{Dg}^{-1}$ & 2.4 \\
metabolizable energy ${ }^{2}, \mathrm{Mcal}^{-1} \mathrm{DM}$ & 1.9 \\
\hline
\end{tabular}

${ }^{1}$ contained: $\mathrm{kg}^{-1} \cdot \mathrm{g}$ : Ca 240, P 71, K 28.2, S 20, Mg 20; mg : Co 30, Cu 400, Fe 2 50, Mn 1350, Se 15, Zn 1700, I 40, Cr 10, F 710; IU: vit. A 135000 , vit. $D_{3} 68000$, vit. $E 450 ;{ }^{2}$ means of digestible energy and metabolizable energy at the level of ad libitum feeding calculated according to the NRC (2001) and NRC (2000), respectively 
access to fresh water. The amounts of feed offered and refused were weighed and recorded to calculate intake. Daily samples of the feed offered and refused were collected and frozen at $-20^{\circ} \mathrm{C}$, and subsequently homogenized to form a composite sample for each animal. Then, the composite samples were pre-dried in a forced ventilation oven at $55^{\circ} \mathrm{C}$ for $72 \mathrm{~h}$, ground to pass a 1-mm screen (Wiley mill, Marconi, MA580, Piracicaba, Brazil) and stored in sealed plastic containers for subsequent analyses.

Indigestible neutral detergent fibre (iNDF) was used as an internal marker to estimate the total production of faeces. Faecal samples were collected directly from the rectum of the animals at $08.00 \mathrm{~h}$ on the $15^{\text {th }}$ day, at $12.00 \mathrm{~h}$ on the $17^{\text {th }}$ day, and at $16.00 \mathrm{~h}$ on the $19^{\text {th }}$ day of each experimental period of 29 days (Chizzotti et al., 2007). Then, the faeces samples from both collection periods were predried at $55^{\circ} \mathrm{C}$, ground to a particle size of $1 \mathrm{~mm}$ and homogenized to form a composite sample for each animal. The samples of feed offered and refused and faeces were incubated in the rumen of a fistulated cattle for $240 \mathrm{~h}$ in non-woven bags $\left(100 \mathrm{~g} \cdot \mathrm{m}^{-2}\right)$, in duplicate (Casali et al., 2008). After incubation, the bags were washed with water and boiled with neutral detergent for one $h$ in an autoclave, and then washed again with distilled water and acetone for subsequent drying in an oven at $55^{\circ} \mathrm{C}$ for $72 \mathrm{~h}$. The production of faecal dry matter was obtained by dividing the intake of iNDF by the iNDF concentration in faeces (Cochran et al., 1986).

The values of DM, ash, organic matter (OM), crude protein $(\mathrm{CP})$ and ether extract $(\mathrm{EE})$ were determined according to the method of AOAC (1990). The contents of neutral detergent fibre (NDF) were determined according to the methodology described by Pell and Schofield (1993). The non-fibre carbohydrates (NFC) were calculated as:

$$
\mathrm{NFC}=100-(\% \text { ash }+\% \mathrm{CP}+\% \mathrm{EE}+\% \mathrm{NDF}) .
$$

The digestibility coefficients (DC) of the nutrients were calculated using the following formula: nutrient:

$$
\begin{gathered}
\mathrm{DC}(\%)=100 \times[100-(\% \text { iNDF intake } / \% \text { iNDF } \\
\text { of faeces }) \times(\% \text { of nutrient in the faeces } / \% \\
\text { of nutrient intake })] .
\end{gathered}
$$

The apparent intake of total digestible nutrients (TDN) was calculated (Sniffen et al., 1992) as:

$\mathrm{TDN}=(\mathrm{CP}$ intake - faecal $\mathrm{CP})+(\mathrm{NDF}$ intake - faecal NDF) + (NFC intake - faecal NFC) $+[2.25 \times($ EE intake - faecal EE $)]$.

The digestible energy intake (DEI) was estimated from the following equation (NRC, 2001):

$$
\begin{gathered}
\text { DEI }(\text { Mcal })=(\mathrm{DCP} \times 5.6)+(\mathrm{DNDF} \times 4.2) \\
+(\mathrm{DNFC} \times 4.2)+(\mathrm{DEE} \times 9.4)
\end{gathered}
$$

where: DCP, DNDF, DNFC and DEE mean, respectively, digestible crude protein, digestible neutral detergent fibre, digestible non-fibre carbohydrates and digestible ether extract $(\mathrm{kg})$.

The metabolizable energy intake (MEI) was considered to be $82 \%$ of the DEI (NRC, 2000). Values TDN, DEI and MEI were divided by dry matter intake (DMI) to calculate the energy concentration at each level of the feed supply.

The evaluation of ingestive behaviour was made by visual observation of each lamb every $10 \mathrm{~min}$ over $24 \mathrm{~h}$ (Johnson and Combs, 1991). The observations were made on the $14^{\text {th }}$ day of each experimental period to determine the time spent feeding, ruminating and resting. Artificial illumination was used during the nocturnal observation. The intake efficiency and rumination efficiency of DM and NDF and total chewing time (TCT) were calculated using the following formulas:

$$
\begin{aligned}
& \mathrm{IEDM}=\mathrm{DMI} / \mathrm{TF} \\
& \mathrm{IENDF}=\mathrm{NDFI} / \mathrm{TF} \\
& \mathrm{REDM}=\mathrm{DMI} / \mathrm{TR} \\
& \mathrm{RENDF}=\mathrm{NDFI} / \mathrm{TR} \\
& \mathrm{TCT}=\mathrm{TF}+\mathrm{TR}
\end{aligned}
$$

where: IEDM - intake efficiency of DM $\left(\mathrm{g} \cdot \mathrm{h}^{-1}\right)$; IENDF - intake efficiency of NDF $\left(g \cdot h^{-1}\right)$; REDM - rumination efficiency of DM $\left(g \cdot h^{-1}\right)$; RENDF - rumination efficiency of NDF $\left(g \cdot h^{-1}\right)$; DMI - dry matter intake $\left(g \cdot \mathrm{d}^{-1}\right)$; TF - time spent feeding $\left(h \cdot d^{-1}\right)$; NDFI - neutral detergent fibre intake $\left(g \cdot d^{-1}\right) ; T R$ - time spent ruminating $\left(h \cdot d^{-1}\right)$.

The rumination time was also expressed in minutes per gram of DM and NDF ingested.

The data analysis was performed using PROC GLM of SAS (Statistical Analysis System, version 9.1 ; 2003), with a significance level of $5 \%$, according to the following statistical model:

$$
\mathrm{Y}=\mu+\alpha+\beta+\alpha \beta+\mathrm{e}
$$

where: $\mu$ - mean; $\alpha$ - effect of feeding level; $\beta$ - effect of sexual class; $\alpha \beta$ - interaction between feeding level with the sexual class; $\mathrm{e}$-random error.

\section{Results}

Regarding DMI, DMI as a percentage of body weight, organic matter intake (OMI), crude protein intake (CPI), neutral detergent fibre intake (NDFI) and non-fibre carbohydrate intake (NFCI), there 
Table 3. Intake of lambs fed ad libitum (AL) or restricted at $70 \%$ or $80 \%$ of ad libitum intake

\begin{tabular}{llll}
\hline Intake & Feeding level & \\
\cline { 2 - 4 } & ad libitum & $70 \%$ & $80 \%$ \\
\hline Dry matter, $\mathrm{kg} \cdot \mathrm{d}^{-1}$ & $1.17^{\mathrm{a}} \pm 0.02$ & $0.35^{\mathrm{b}} \pm 0.01$ & $0.24^{\mathrm{c}} \pm 0.00$ \\
Dry matter, \% BW & $4.04^{\mathrm{a}} \pm 0.06$ & $1.88^{\mathrm{b}} \pm 0.04$ & $1.52^{\mathrm{c}} \pm 0.02$ \\
Ash, $\mathrm{kg} \cdot \mathrm{d}^{-1}$ & $0.09^{\mathrm{a}} \pm 0.00$ & $0.03^{\mathrm{b}} \pm 0.00$ & $0.02^{\mathrm{c}} \pm 0.00$ \\
Organic matter, $\mathrm{kg} \cdot \mathrm{d}^{-1}$ & $1.10^{\mathrm{a}} \pm 0.02$ & $0.32^{\mathrm{b}} \pm 0.01$ & $0.21^{\mathrm{c}} \pm 0.00$ \\
Crude protein, $\mathrm{kg} \cdot \mathrm{d}^{-1}$ & $0.26^{\mathrm{a}} \pm 0.00$ & $0.07^{\mathrm{b}} \pm 0.00$ & $0.05^{\mathrm{c}} \pm 0.00$ \\
Neutral detergent fibre, $\mathrm{kg} \cdot \mathrm{d}^{-1}$ & $0.44^{\mathrm{a}} \pm 0.01$ & $0.14^{\mathrm{b}} \pm 0.00$ & $0.10^{\mathrm{c}} \pm 0.00$ \\
Ether extract, $\mathrm{kg} \cdot \mathrm{d}^{-1}$ & $0.02 \pm 0.00$ & $0.01 \pm 0.00$ & $0.01 \pm 0.00$ \\
Non-fibre carbohydrates, $\mathrm{kg} \cdot \mathrm{d}^{-1}$ & $0.36^{\mathrm{a}} \pm 0.00$ & $0.10^{\mathrm{b}} \pm 0.00$ & $0.07^{\mathrm{c}} \pm 0.00$ \\
\hline
\end{tabular}

${ }^{1}$ percentage of body weight; means in the same row followed by different letters differ in Tukey test at $5 \%$ probability; there was no effect of sexual class, or interaction of sexual class with feeding level $(P>0.05)$

Table 4. Digestibility coefficients and values of dietary energy of lambs fed ad libitum or restricted at $70 \%$ or $80 \%$ of ad libitum intake

\begin{tabular}{|c|c|c|c|}
\hline \multirow{2}{*}{ Indices } & \multicolumn{3}{|c|}{ Feeding level } \\
\hline & ad libitum & $70 \%$ & $80 \%$ \\
\hline \multicolumn{4}{|l|}{ Digestibility, \% } \\
\hline dry matter ${ }^{1}$ & $53.4^{\mathrm{b}} \pm 1.1$ & $67.2^{\mathrm{a}} \pm 0.4$ & $67.6^{\mathrm{a}} \pm 0.7$ \\
\hline organic matter ${ }^{1}$ & $56.5^{\mathrm{b}} \pm 1.0$ & $69.6^{\mathrm{a}} \pm 0.3$ & $70.3^{\mathrm{a}} \pm 0.7$ \\
\hline crude protein ${ }^{1}$ & $58.9^{b} \pm 1.6$ & $77.0^{\mathrm{a}} \pm 0.8$ & $80.3^{a} \pm 0.7$ \\
\hline ether extract ${ }^{1}$ & $26.4^{b} \pm 1.5$ & $52.7^{\mathrm{a}} \pm 1.4$ & $56.4^{\mathrm{a}} \pm 1.8$ \\
\hline non-fibre carbohydrates ${ }^{1}$ & $89.0^{b} \pm 1.0$ & $94.0^{\mathrm{a}} \pm 0.4$ & $96.7^{\mathrm{a}} \pm 0.5$ \\
\hline neutral detergent fibre ${ }^{1}$ & $28.4^{b} \pm 1.2$ & $46.7^{\mathrm{a}} \pm 0.9$ & $44.8^{a} \pm 0.8$ \\
\hline Total digestible nutrients, $\%$ & $52.0^{\mathrm{b}} \pm 0.7$ & $64.7^{\mathrm{a}} \pm 0.6$ & $65.5^{\mathrm{a}} \pm 0.7$ \\
\hline Digestible energy, Mcal kg-1 $\mathrm{DM}^{2}$ & $2.37^{\mathrm{b}} \pm 0.1$ & $2.94^{\mathrm{a}} \pm 0.1$ & $2.97^{a} \pm 0.1$ \\
\hline Metabolizable energy, Mcal kg-1 $\mathrm{DM}^{2}$ & $1.94^{b} \pm 0.0$ & $2.41^{\mathrm{a}} \pm 0.0$ & $2.44^{\mathrm{a}} \pm 0.0$ \\
\hline
\end{tabular}

${ }^{1}$ apparent digestibility; ${ }^{2} \mathrm{dry}$ matter; means in the same row followed by different letters differ in Tukey test at $5 \%$ probability; there was no effect of sexual class, or interaction of sexual class with feeding level $(P>0.05)$

was no effect of sexual class or interaction of sexual class with feeding level $(P>0.05)$. In contrast, there was an effect $(P<0.05)$ of feeding level on all of these variables, with the highest values of DMI and nutrient intake presented by animals fed ad libitum, followed by $70 \%$ restriction, and lowest at $80 \%$ restriction (Table 3 ).

There was no effect of sexual class or interaction of sexual class with feeding level regarding digestibility coefficients and the levels of TDN, digestible energy (DE) and metabolizable energy (ME) $(P>0.05)$. Inversely, there were significant differences $(P<0.05)$ between feeding levels (Table 4$)$. The apparent digestibility of dry matter (DMD), organic matter (OMD), crude protein (CPD), ether extract (EED), non-fibre carbohydrates (NFCD) and true digestibility of neutral detergent fibre (NDFD) were lower $(P<0.05)$ for animals fed ad libitum compared with the values presented by the animals submitted to feed restriction of $70 \%$ and $80 \%$, which did not differ $(P>0.05)$. Regarding the concentrations of TDN, DE and ME in the diet, the obtained values were lower $(P<0.05)$ on the ad libitum feeding compared with those when feed was restricted by $70 \%$ and $80 \%$, which did not differ $(P>0.05)$.

Ingestive behaviour did not differ among sexual classes and there was no interaction of sexual classes with feeding levels $(P>0.05)$. The feeding levels did, however, influence the values of ingestive behaviour parameters (Table 5). The average time spent on feeding and ruminating was higher $(P<0.05)$ for animals maintained on ad libitum feeding, which consequently had higher total chewing time (TCT) and lower resting time $(P<0.05)$ compared with feed-restricted animals, which did not differ $(P>0.05)$.

There was no difference $(P>0.05)$ between feeding levels regarding IEDM and IENDF values (Table 5). On the other hand, the values of REDM and RENDF were affected by the feeding levels, and were higher $(P<0.05)$ in animals fed ad libitum compared with those submitted to $70 \%$ and $80 \%$ restriction, which did not differ $(P>0.05)$. In addition, the feeding levels also influenced $(P<0.05)$ the rumination time of DM (RTDM) and rumination time of NDF (RTNDF), and the highest values were observed in the animals submitted to $80 \%$ feed restriction. Conversely, the lowest values were presented by lambs fed ad libitum. Animals kept at $70 \%$ restriction showed intermediary RTDM and RTNDF.

There was no effect $(P>0.05)$ of sexual class or interaction of sexual class with the feeding level on slaughter body weight (SBW), total body weight gain (TBWG), ADG or FE of NDL. The feeding 
Table 5. Ingestive behaviour of lambs fed ad libitum or restricted at $70 \%$ or $80 \%$ of ad libitum intake

\begin{tabular}{lrrr}
\hline Indices & Feeding level & \\
\cline { 2 - 4 } & ad libitum & \multicolumn{1}{c}{$70 \%$} & \multicolumn{1}{l}{$0 \%$} \\
\hline Feeding, $\mathrm{h} \cdot \mathrm{d}^{-1}$ & $4.0^{\mathrm{a}} \pm 0.2$ & $0.88^{\mathrm{b}} \pm 0.0$ & $0.93^{\mathrm{b}} \pm 0.1$ \\
Resting, $\mathrm{h} \cdot \mathrm{d}^{-1}$ & $15.0^{\mathrm{b}} \pm 0.5$ & $20.1^{\mathrm{a}} \pm 0.1$ & $20.2^{\mathrm{a}} \pm 0.2$ \\
Ruminating, $\mathrm{h} \cdot \mathrm{d}^{-1}$ & $5.4^{\mathrm{a}} \pm 0.3$ & $3.0^{\mathrm{b}} \pm 0.1$ & $2.8^{\mathrm{b}} \pm 0.2$ \\
Total chewing time, $\mathrm{h} \cdot \mathrm{d}^{-1}$ & $9.4^{\mathrm{a}} \pm 0.4$ & $3.9^{\mathrm{b}} \pm 0.1$ & $3.8^{\mathrm{b}} \pm 0.2$ \\
Intake efficiency of dry matter, $\mathrm{g} \cdot \mathrm{h}^{-1}$ & $330 \pm 24$ & $441 \pm 23$ & $325 \pm 25$ \\
Intake efficiency of NDF, $\mathrm{g} \cdot \mathrm{h}^{-1}$ & $124 \pm 8.8$ & $179 \pm 9.4$ & $132 \pm 10$ \\
Rumination efficiency of dry matter, $\mathrm{g} \cdot \mathrm{h}^{-1}$ & $259^{\mathrm{a}} \pm 20$ & $127^{\mathrm{b}} \pm 8.5$ & $98^{\mathrm{b}} \pm 8.5$ \\
Rumination efficiency of $\mathrm{NDF}^{1}, \mathrm{~g} \cdot \mathrm{h}^{-1}$ & $9^{\mathrm{a}} \pm 7.4$ & $52^{\mathrm{b}} \pm 3.5$ & $40^{\mathrm{b}} \pm 3.4$ \\
Rumination time per dry matter, $\mathrm{min} \cdot \mathrm{g}^{-1}$ & $0.29^{\mathrm{c}} \pm 0.0$ & $0.53^{\mathrm{b}} \pm 0.0$ & $0.74^{\mathrm{a}} \pm 0.0$ \\
Rumination time per NDF \\
\hline
\end{tabular}

${ }^{1}$ neutral detergent fibre; means in the same row followed by different letters differ in Tukey test at $5 \%$ probability; there was no effect of sexual class, or interaction of sexual class with feeding level $(P>0.05)$

Table 6. Performance of lambs fed ad libitum (AL) or restricted at 70\% or $80 \%$ of ad libitum intake

\begin{tabular}{|c|c|c|c|}
\hline \multirow{2}{*}{ Indices } & \multicolumn{3}{|c|}{ Feeding level } \\
\hline & ad libitum & $70 \%$ & $80 \%$ \\
\hline Initial body weight, $\mathrm{kg}$ & $18.1 \pm 0.4$ & $18.0 \pm 0.4$ & $18.1 \pm 0.4$ \\
\hline Slaughter body weight, kg & $29.1^{\mathrm{a}} \pm 0.3$ & $18.7^{b} \pm 0.4$ & $15.5^{c} \pm 0.3$ \\
\hline Total body weight gain, $\mathrm{kg}$ & $11.1^{\mathrm{a}} \pm 0.4$ & $0.7^{b} \pm 0.4$ & $-2.6^{c} \pm 0.2$ \\
\hline Average daily gain, $\mathrm{kg} \cdot \mathrm{d}^{-1}$ & $0.19^{\mathrm{a}} \pm 0.0$ & $0.03^{b} \pm 0.0$ & $-0.05^{\complement} \pm 0.0$ \\
\hline $\begin{array}{l}\text { Feed efficiency, } \\
\mathrm{kg} \mathrm{ADG}^{1} \cdot \mathrm{kg}^{-1} \cdot \mathrm{DMI}^{2}\end{array}$ & $0.17^{\mathrm{a}} \pm 0.0$ & $0.08^{b} \pm 0.0$ & $-0.19^{c} \pm 0.0$ \\
\hline
\end{tabular}

${ }^{1}$ average daily gain; ${ }^{2}$ dry matter intake; means in the same row followed by different letters differ in Tukey test at $5 \%$ probability; there was no effect of sexual class, or interaction of sexual class with feeding level $(P>0.05)$

levels did, however, affect the performance of the animals (Table 6). SBW, TBWG, ADG and FE were greater $(P<0.05)$ for lambs fed ad libitum. Animals subjected to restriction of $70 \%$ had lower values compared with those fed ad libitum, but were higher $(P<0.05)$ than the values obtained by lambs under $80 \%$ restriction, which in turn lost weight and were negative for TBWG, ADG and FE.

\section{Discussion}

Carvalho et al. (1999) and Rodríguez et al. (2008) also found no effect of sexual class on DMI or nutrient intake in lambs. According to the NRC (2000), gender has a limited effect on animal feed intake and the differences are generally attributed to different stages of body maturity reached by genders.

With regard to digestibility, the results are consistent with those described by Galvani et al. (2010) and Dias et al. (2011) who observed, respectively, higher DMD and nutrient digestibility in sheep and cattle subjected to feed restriction. The lowest DC presented by the ad libitum treatment may be explained due to the increase in the passage rate of feed particles through the reticulum-rumen and the lower retention time of digesta through the gastrointestinal tract due to the higher level of DM (Dias et al., 2011). The increase in the passage rate is due to a greater flow pressure caused by ingestion of more feed and exerted on the residue and potentially digestible organic matter present in the gastrointestinal tract (Van Soest, 1982).

The lower CPD of animals fed may also be attributed to increased excretion of endo-genous $\mathrm{CP}$ in faeces, as well as increased excretion of microbial $\mathrm{CP}$ residues, which are positively correlated with DMI (Cannas et al., 2004).

The lowest values of TDN, DE and ME in the feeding level may be due to reductions in DC of nutrients with the highest level of intake, which is consistent with NRC (2001) recommendations for the energy value of feeds, which is reduced every multiple of intake above maintenance.

The longer time spent on the activities of eating, ruminating and chewing presented by animals fed ad libitum may be explained by virtue of their greater DMI. The lack of effect of feeding levels on the values of IEDM and IENDF may be partially explained by the composition of the diet, which was the same among treatments, with the same forage:concentrate ratio. In addition, the lower feed supply was compensated by a shorter feeding time of animals subjected to restraint, thereby DMI and feeding time varied proportionately. These results are consistent with those described by Ribeiro et al. (2006) and Cândido et al. (2012), who observed no effect of feed restriction on the IEDM and IENDF in goats and cattle, respectively.

The highest values of REDM and RENDF presented by animals fed ad libitum may be explained on the basis of their higher DMI and NDFI. According to Dulphy et al. (1980), the RENDF is increased when there is a larger fibre intake by ruminants. A similar result was described by Cândido et al. (2012), who observed higher values of REDM 
and RENDF in cattle fed ad libitum compared with those submitted to feed restriction.

Galvani et al. (2010) also observed greater RTDM in lambs subjected to feed restriction. The highest values of RTDM and RTNDF obtained with dietary restriction may be related to higher ruminal retention of feed particles, caused by the lower level of intake, which is an adaptive mechanism of ruminants to provide greater nutrient digestibility under conditions of feed restriction (Dias et al., 2011). This result could explain the higher DC presented by animals subjected to feed restriction, especially in relation to NDFD, since the fibre particles need a longer ruminal fermentation time to be degraded compared with easily digestible nutrients (Clauss et al., 2010).

Carvalho et al. (1999) and Rodríguez et al. (2008) also did not observe differences between sexual classes on SBW, ADG or FE. Moreover, the present results differ from those shown by Ferrell et al. (1979) and Siqueira et al. (2001), in which non-castrated lambs had higher SBW, ADG and FE compared with females and castrated males, and this difference was attributed to the physiological function of testosterone, which is responsible for higher deposition of muscle mass, and consequently, higher ADG and FE in males (Schanbacher et al., 1980; Jenkins et al., 1988). The non-castrated lambs slaughtered at seven months of age would probably have been at the onset of puberty, thus, the anabolic effect of testosterone may not have occurred with greater intensity.

Pereira Filho et al. (2005) and Yáñez et al. (2006) also observed lower values of SBW, ADG and FE in goats subjected to feed restriction as compared with ad libitum feeding. Animals use energy for tissue gain after satisfying their demand for maintenance, which represents most of the expenditure of metabolizable energy (Williams and Jenkins, 2003). Thus, even increasing the digestibility of nutrients with dietary restriction, this mechanism was not enough to offset lower intake. Thus, with lower feed supply, less energy was available for gain, reducing the FE.

\section{Conclusions}

Feed restriction affects ingestive behaviour and nutrient digestibility of non-descript breed hair lambs (NDL), which spend more time ruminating the digesta and have higher digestibility. Animals subjected to $80 \%$ restriction have lower performance compared with animals maintained at $70 \%$ restriction. Sexual class does not affect the intake, digestibility, ingestive behaviour, or performance of NDL.

\section{Acknowledgements}

This research was financed by the Fundação de Amparo à Ciência e Tecnologia do Estado de Pernambuco - FACEPE (Brazil), the Conselho Nacional de Desenvolvimento Científico e Tecnológico - CNPq (Brazil), and the Coordenação de Aperfeiçoamento de Pessoal de Nível Superior - CAPES (Brazil).

\section{References}

AOAC, 1990. Association of Official Analytical Chemists, Official Methods of Analysis. $15^{\text {th }}$ Edition. Washington, DC

Cândido E.P., Gonzaga Neto S., Bezerra L.R., Saraiva E.P., Pimenta Filho E.C., Araujo G.G.L., 2012. Ingestive behavior of Guzerat and Sindhi heifers under the effects of feed restriction. Acta Sci. Anim. Sci. 34, 297-303

Cannas A., Tedeschi L.O., Fox D.G., Pell A.N., Van Soest P.J., 2004. A mechanistic model for predicting the nutrient requirements and feed biological values for sheep. J. Anim. Sci. 82, 149-169

Carvalho S., Pires C.C., Peres J.R., Zeppenfeld C., Weiss A., 1999. Performance of whole males lambs, castrated males lambs and females lambs, feed in confinement (in Spanish). Cienc. Rural. 29, 129-133

Casali A.O., Detmann E., Valadares Filho S.C., Pereira J.C., Henriques L.T., Freitas S.G., Paulino M.F., 2008. IInfluence of incubation time and particles size on indigestible compounds contents in cattle feeds and feces obtained by in situ procedures (in Spanish). Rev. Bras. Zootec. 37, 335-342

Chizzotti M.L., Valadares Filho S.C., Tedeschi L.O., Chizzotti F.H.M., Carstens G.E., 2007. Energy and protein requirements for growth and maintenance of F1 Nellore x Red Angus bulls, steers, and heifers. J. Anim. Sci. 85, 1971-1981

Clauss M., Hume I.D., Hummel J., 2010. Evolutionary adaptations of ruminants and their potential relevance for modern production systems. Animal 4, 979-992

Cochran R.C., Adans D.C., Wallace J.D., Galyean M.L., 1986. Predicting digestibility of different diets with internal markers: evaluation of four potential markers. J. Anim. Sci. 63, 1476-1483

Dias R.S., Patino H.O., López S., Prates E., Swanson K.C., France J., 2011. Relationships between chewing behavior, digestibility, and digesta passage kinetics in steers fed oat hay at restricted and ad libitum intakes. J. Anim. Sci. 89, 1873-1880

Dulphy J.P., Remond B., Theriez M., 1980. Ingestive behavior and related activities in ruminants. In: Y. Ruckebush, P. Thivend (Editors). Digestive Physiology and Metabolism in Ruminants. MTP Press. Lancaster, pp.103-122

Ferrell C.L., Crouse J.D., Field R.A., Chant J.L., 1979. Effect of sex, diet and stage of growth upon energy utilization by lambs. J. Anim. Sci. 49, 790-801

Galvani D.B., Pires C.C., Wommer T.P., Oliveira F., Santos M.F., 2010. Chewing patterns and digestion in sheep submitted to feed restriction. J. Anim. Physiol. Anim. Nutr. 94, 366-373

IBGE, 2012. Brazilian Institute of Geography and Statistics, Municipal Livestock Production (in Spanish). IBGE. Rio de Janeiro

Jenkins T.G., Ford J.J., Klindt J., 1988. Postweaning growth, feed efficiency and chemical composition of sheep as affected by prenatal and postnatal testosterone. J. Anim. Sci. 66, 1179-1185

Johnson T.R., Combs D.K., 1991. Effects of prepartum diet, inert rumen bulk, and dietary polyethylene glycol on dry matter intake of lactating dairy cows. J. Dairy Sci. 74, 933-944 
NRC, 2000. Nutrient Requirements of Beef Cattle. $7^{\text {th }}$ Edition. National Academy Press. Washington, DC

NRC, 2001. Nutrient Requirements of Dairy Cattle. $7^{\text {th }}$ Edition. National Academy Press. Washington, DC

NRC, 2007. Nutrient Requirements of Small Ruminants: Sheep, Goats, Cervids, and New World Camelids. National Academy Press. Washington, DC

Pell A.N., Schofield P., 1993. Computerized monitoring of gas production to measure forage digestion in vitro. J. Dairy Sci. 76, 1063-1073

Pereira Filho J.M., Resende K.T., Teixeira I.A.M.A., Silva Sobrinho A.G., Yáñez E.A., Ferreira A.C.D., 2005. Effect of feed restriction on economical and productive performances of F1-Boer x Saanen goats (in Spanish). Rev. Bras. Zootec. 34, 188-196

Ribeiro V.L., Batista A.M.V., Carvalho F.F.R., Mattos C.W., Alves K.S., 2006. Ingestive behavior of Moxotó and Canindé goats submitted to ad libitum and restricted feeding (in Spanish). Acta Sci. Anim. Sci. 28, 331-337

Rodríguez A., Bodas R., Prieto N., Landa R., Mantecón A., Giráldez F., 2008. Effect of sex and feeding system on feed intake, growth, and meat and carcass characteristics of fattening Assaf lambs. Livest. Sci. 116, 118-125
Schanbacher B.D., Crouse J.D., Ferrell C.L.,1980. Testosterone influences on growth, performance, carcass characteristics and composition of young market lambs. J. Anim. Sci. 51, 685-691

Siqueira E.R., Simões C.D., Fernades S., 2001. Effects of sex and slaughter weight on meat production of lambs. 1. Growth rate, carcass quantitative traits, meat $\mathrm{pH}$ and economic results (in Spanish). Rev. Bras. Zootec. 30, 844-848

Sniffen C.J., O'Connor J.D., Van Soest P.J., Fox D.G., Russell J.B., 1992. A net carbohydrate and protein system for evaluating cattle diets: II. Carbohydrate and protein availability. J. Anim. Sci. 70, 3562-3577

Van Soest P.J., 1982. Nutritional Ecology of the Ruminant. O and B Books. Cornvallis, pp. 374

Williams C.B., Jenkins T.G., 2003. A dynamic model of metabolizable energy utilization in growing and mature cattle. I. Metabolizable energy utilization for maintenance and support metabolism. J. Anim. Sci. 81, 1371-1381

Yáñez E.A., Resende K.T., Ferreira A.C.D., Pereira Filho J.M., Silva Sobrinho A.G., Teixeira I.A.M.A., Medeiros A.N., 2006. Feed restriction in goats: carcass yield, commercial cuts, and carcass composition (in Spanish). Rev. Bras. Zootec. 35, 2093-2100 